\title{
Oxytocin is luteolytic in the rhesus monkey (Macaca mulatta)
}

\author{
F. J. Auletta, Deborah K. Paradis, Mary Wesley and R. T. Duby* \\ University of Vermont College of Medicine, Department of Obstetrics \& Gynecology \& Biochemistry, \\ Burlington, Vermont 05405, and ${ }^{*}$ University of Massachusetts, Department of Veterinary and \\ Animal Sciences, Amherst, Massachusetts 01002, U.S.A.
}

\begin{abstract}
Summary. Oxytocin $(10 \mathrm{mi} . \mathrm{u} . / \mu \mathrm{l} / \mathrm{h})$ or vehicle $(0.5 \%$ chlorobutanol in saline, $1 \mu \mathrm{l} / \mathrm{h})$ was chronically infused directly into the corpus luteum of normally cyclic rhesus monkeys, by means of an Alzet pump-ovarian cannula system. Infusion of oxytocin $(\mathbf{N}=6)$ or vehicle $(\mathrm{N}=5)$ began 6 days after the preovulatory oestradiol surge, and daily peripheral blood samples were taken. Oxytocin caused a significant $(P<0.05)$ decrease in progesterone, beginning 1 day after treatment, and oestradiol after 4 days; progesterone and oestradiol remained significantly depressed until menstruation. However, peripheral LH concentrations remained unchanged. The duration of the luteal phase, menstrual cycle and the onset of menses from the initiation of oxytocin infusion were significantly $(P<0.01)$ shorter when compared to those of vehicletreated controls. These results show that oxytocin can induce functional luteolysis in the primate and supports the hypothesis that oxytocin of luteal origin may play a role in spontaneous luteolysis.
\end{abstract}

\section{Introduction}

Exogenously administered oxytocin has been shown to induce premature luteal regression in several domestic animals (Armstrong \& Hansel, 1959; Milne, 1963; Black \& Duby, 1965; Auletta, Currie \& Black, 1972a; Cooke \& Knifton, 1981). The neurohypophysial hormones, oxytocin and vasopressin, have been isolated from the human corpus luteum (Wathes et al., 1982). Oxytocin has also been identified in the bovine (Fields, Eldridge, Fuchs, Roberts \& Fields, 1983), ovine (Wathes \& Swann, 1982) and monkey (Khan-Dawood, Marut \& Dawood, 1984) corpus luteum, and in human ovarian stroma and preovulatory follicles (Khan-Dawood \& Dawood, 1983). A potential role for endogenous ovarian oxytocin in regulating luteal function is supported by several new observations of sheep: (1) luteolysis is delayed in sheep immunized against oxytocin (Sheldrick, Mitchell \& Flint, 1980); (2) peripheral blood concentrations of oxytocin (Sheldrick \& Flint, 1981) and neurophysins (Fairclough et al., 1980) parallel progesterone values throughout the life-span of the corpus luteum, and (3) oxytocin is selectively released into the ovarian venous effluent ipsilateral to the corpus luteum after systemic administration of a potent prostaglandin (PG) F- $2 \alpha$ analogue, cloprostenol (Flint \& Sheldrick, 1982). Collectively, these studies suggest that oxytocin modulates the luteolytic action of PGF- $2 \alpha$ in sheep. In primates, however, measurement of oxytocin in the peripheral circulation has not revealed any significant changes associated with luteal regression (Falconer, Mitchell, Mountford \& Robinson, 1980; Mitchell, Haynes, Anderson \& Turnbull, 1981). Nevertheless, Tan, Tweedale \& Biggs (1982) reported that high concentrations of oxytocin (400-800 mi.u./ml) caused inhibition of basal and hCG-stimulated progesterone production by dispersed human luteal cells in vitro. We have now studied the effects of continuous infusion of oxytocin directly into the corpus luteum of rhesus monkeys. 


\section{Materials and Methods}

Rhesus monkeys (Macaca mulatta), purchased from National Institutes of Health and exhibiting at least one normal, ovulatory menstrual cycle, were used. Daily vaginal lavage (to determine the onset and duration of menstrual bleeding) and serial peripheral blood progesterone, oestradiol and LH concentrations, were used to document cyclic activity. In the luteal phase, a progesterone value $>2 \mathrm{ng} / \mathrm{ml}$ was considered indicative of an ovulatory cycle (Auletta, Caldwell, van Wagenen \& Morris, 1972b). During the treatment cycle, blood was taken by femoral or saphenous vein puncture on Days 10-18 from the onset of menses, to determine the day of the preovulatory oestradiol surge. Consequently, a daily blood sample was withdrawn for the measurement of progesterone and oestradiol by radioimmunoassays (Auletta, Agins \& Scommegna, 1978) and LH by the rat interstitial cell testosterone assay (Auletta, Kamps, Pories, Bisset \& Gibson, 1984). A sensitivity of $1.5 \mathrm{ng}$ of LH (LER 1909-2) per tube when assaying 20-50 $\mu \mathrm{l}$ of plasma in the RICT was achieved; the intra-assay and interassay coefficients of variation were $6.3 \%$ and $10 \cdot 4 \%$ respectively (Auletta et al., 1984a). The sensitivity of the progesterone RIA was $50 \mathrm{pg} / \mathrm{tube}$ when assaying $200 \mu \mathrm{l}$ plasma; the intra-assay and interassay coefficients of variation were $4.6 \%$ and $7 \cdot 2 \%$ respectively (Auletta, Agins \& Scommegna, 1978). The sensitivity of the oestradiol RIA was $6 \mathrm{pg} /$ tube when assaying $100 \mu \mathrm{l}$ of plasma, and the intra- and interassay variations were $7 \cdot 4 \%$ and $11 \cdot 3 \%$ respectively (Auletta, Agins \& Scommegna, 1978).

At 6 days after the preovulatory oestradiol surge, a laparotomy was performed under sterile conditions using pentobarbitone sodium anaesthesia $(20 \mathrm{mg} / \mathrm{kg}$ body weight), and the ovary bearing the corpus luteum was identified and a cannula introduced. The technique for the insertion of the Alzet pump-cannula system into the corpus luteum has been published elsewhere (Auletta $e t$ $a l ., 1984)$. The following is a brief description of our technique. The ovarian capsule was punctured with an 18-gauge needle, and a polyvinyl no. 2 cannula, connected to an Alzet osmotic mini-pump (Model 2001 ; Alza Corporation, Palo Alto, CA, U.S.A.), was inserted through the subjacent stroma directly into the corpus luteum $(\sim 5 \mathrm{~mm})$. The cannula was secured to the ovary with one $5-0$ absorbable suture and one drop of 9-10 adhesive (Eastman Kodak, Rochester, NY, U.S.A.) on the suture knot. Before closure, a separate stab incision in the flank allowed exteriorization of the pump, which was secured subcutaneously, making the pump easily accessible for changing. The cannula and Alzet pump were pre-filled with oxytocin (Sigma Chemical Company, St Louis, MO, U.S.A.) (Grade X, 500 i.u./mg) or vehicle $(0.5 \%$ chlorobutanol in $0.9 \%(\mathrm{w} / \mathrm{v}) \mathrm{NaCl})$. The model 2001 pump delivers $1 \mu \mathrm{l}$ solute/h for 7 days (Theeuwes \& Yum, 1970). Oxytocin $(10 \mathrm{mi} . \mathrm{u} . / \mu \mathrm{l} / \mathrm{h}$ ) or vehicle $(1 \mu \mathrm{l} / \mathrm{h})$ was continuously infused into the corpus luteum until menstruation occurred. The infusion rate of oxytocin $(10 \mathrm{mi} . \mathrm{u} . / \mu \mathrm{l} / \mathrm{h})$ was chosen to approximate physiological rather than pharmacological concentration and is based on our current knowledge of the oxytocin content in human (Wathes et al., 1982; Khan-Dawood \& Dawood, 1983) and monkey (Khan-Dawood et al., 1984) luteal tissue. It was $40-80$-fold lower than the dose used during in-vitro investigations (Tan et $a l ., 1982$ ). However, the actual content of oxytocin in the corpus luteum has not been determined, and therefore the possibility remains that the dose is above the physiological production rate. A second laparotomy was performed 1-5 days after the onset of menstruation during the treatment cycle, and the attachment of the cannula to the ovary was verified before removal.

Hormone concentration data were normalized to the day of the preovulatory oestradiol surge and were statistically assessed using one-way analysis of variance with repeated measurements (Steel \& Torrie, 1960). Significant differences in the intervals of the menstrual cycle were determined by Student's $t$ test.

\section{Results}

Intraluteal infusion of oxytocin caused premature, functional luteolysis in 5 of 6 monkeys. As shown in Table 1, the length of the menstrual cycle, luteal phase, and the time from the initiation of 
Table 1. Intervals of the menstrual cycle as affected by intraluteal infusion of oxytocin or vehicle

\begin{tabular}{|c|c|c|c|c|c|}
\hline \multirow[b]{2}{*}{ Treatment $\dagger$} & \multirow[b]{2}{*}{$\begin{array}{l}\text { No. of } \\
\text { monkeys }\end{array}$} & \multicolumn{4}{|c|}{ Duration in days (mean \pm s.e.m.) } \\
\hline & & $\begin{array}{c}\text { Follicular } \\
\text { phase }\end{array}$ & $\begin{array}{l}\text { Luteal } \\
\text { phase§ }\end{array}$ & $\begin{array}{l}\text { Menstrual } \\
\text { cycle }\end{array}$ & $\begin{array}{l}\text { Onset of menses } \\
\text { from treatment }\end{array}$ \\
\hline $\begin{array}{l}\text { Vehicle to } \\
\text { corpus luteum }\end{array}$ & 5 & $14 \cdot 2 \pm 0 \cdot 5$ & $15 \cdot 8 \pm 0 \cdot 2$ & $30 \cdot 0 \pm 0 \cdot 3$ & $9 \cdot 8 \pm 0.2$ \\
\hline $\begin{array}{l}\text { Oxytocin to } \\
\text { corpus luteum }\end{array}$ & 6 & $13 \cdot 5 \pm 0 \cdot 6$ & $12 \cdot 6 \pm 0 \cdot 3^{*}$ & $26 \cdot 1 \pm 0 \cdot 3^{*}$ & $6 \cdot 8 \pm 0 \cdot 3^{*}$ \\
\hline Untreated & 9 & $14 \cdot 1 \pm 0 \cdot 6$ & $15 \cdot 8 \pm 0 \cdot 3$ & $29.9 \pm 0.5$ & - \\
\hline
\end{tabular}

* $P<0.01$ (Student's $t$ test) compared to values for the other two groups.

$\dagger$ Vehicle $(1 \mu \mathrm{l} / \mathrm{h})$ or oxytocin $(10 \mathrm{mi} . \mathrm{u} . / \mathrm{\mu l} / \mathrm{h})$ directly into the corpus luteum, 6 days after the preovulatory oestradiol surge.

$\ddagger$ From the first day of menstruation until the day of the preovulatory oestradiol surge.

$\S$ From the preovulatory oestradiol surge (Day 0 ) to the day of menstruation.

oxytocin infusion to the onset of menstruation was significantly shorter $(P<0.01)$ when compared to those in vehicle-infused or untreated animals. There were no significant differences in the length of the follicular phase between any groups. Ovarian function, as reflected by monitoring plasma oestradiol and progesterone values, was dramatically impaired in corpora lutea infused with oxytocin (Text-fig. 1). A significant depression in progesterone was observed 1 day after the start of oxytocin infusion (Day 7) with further reductions seen throughout the remainder of the luteal phase, except for the 2 nd day of infusion. Oestradiol values also fell, with significant depressions beginning 4 days after oxytocin infusion (Day 10). At no time were LH levels different from those of vehicle-treated animals. The cyclic patterns of the ovarian steroids and LH in the vehicle-treated animals were identical to patterns in monkeys during unperturbed cycles (not shown) (Auletta et al., 1984).

\section{Discussion}

This investigation represents our continuing effort to reveal the mechanisms(s) involved in primate luteal regression. The use of the Alzet osmotic pump-cannula system has been of great value in testing potential luteolytic agents at the level of the corpus luteum because compounds can be administered chronically to conscious, unrestrained animals.

Our results are the first to show that oxytocin infused directly into the primate corpus luteum causes premature, functional luteolysis, as evidenced by significantly shorter luteal phases, menstrual cycles, and depression of plasma oestradiol and progesterone, without any change in circulating $\mathrm{LH}$. Since high concentrations of immunoreactive oxytocin are present in bovine (Fields et al., 1983), ovine (Wathes \& Swann, 1982), human (Wathes et al., 1982; Khan-Dawood \& Dawood, 1983) and monkey (Khan-Dawood et al., 1984) luteal tissue, and oxytocin inhibits progesterone synthesis by human luteal cells in vitro (Tan et al., 1982), we suggest that oxytocin may play a role in the primate luteolytic process. Alternatively, oxytocin may be non-specifically toxic or unphysiologically disruptive.

We believe, however, that our results do demonstrate a physiological phenomenon because there is a strong precedent for oxytocin as a luteolytic agent in mammals (Armstrong \& Hansel, 1959; Milne, 1963; Black \& Duby, 1965; Auletta et al., 1972a; Cooke \& Knifton, 1981). Oxytocin is released selectively into the ovarian venous effluent on the corpus luteum side in sheep after systemic administration of a potent PGF- $2 \alpha$ analogue (Flint \& Sheldrick, 1982), PGF-2 $\alpha$ is probably the uterine luteolysin in sub-primate mammals (Horton \& Poyser, 1976), and our 


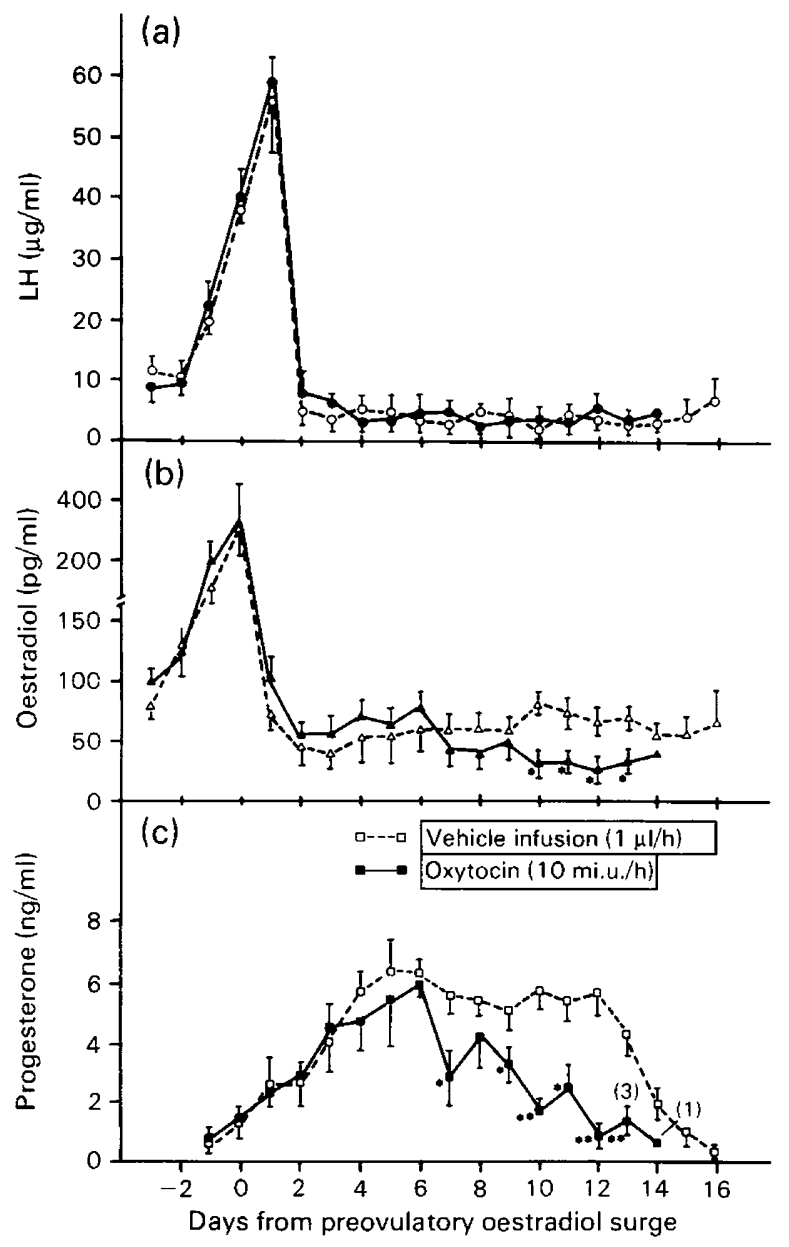

Text-fig. 1. The time course and quantitative changes (mean \pm s.e.m.) in circulating LH (a), oestradiol (b), and progesterone (c) during the preovulatory and luteal phases of the menstrual cycle of monkeys when vehicle $(1 \mu \mathrm{l} / \mathrm{h}, \mathrm{N}=5)$ or oxytocin $(10 \mathrm{mi} . \mathrm{u} \cdot / \mu \mathrm{l} / \mathrm{h}, \mathrm{N}=6)$ was infused directly into the corpus luteum until menstruation. Data are normalized to the preovulatory oestradiol surge. ${ }^{*} P<0.05,{ }^{* *} P<0.01$ compared with values for vehicle-treated controls. Numbers in parentheses in the progesterone panel refer to the monkeys still exhibiting cycles.

intraluteal infusions delivered oxytocin in amounts (10 mi.u./h) equivalent to estimated luteal and ovarian concentrations in women (Wathes et al., 1982; Khan-Dawood \& Dawood, 1983) and monkeys (Khan-Dawood et al., 1984). Luteolysis was also induced in 2 monkeys (not shown) with an intraluteal infusion rate of $100 \mathrm{mi} . \mathrm{u} . / \mathrm{h}$; a dose lower than $10 \mathrm{mi} . \mathrm{u} . / \mathrm{h}$ has not been evaluated.

These data convincingly illustrate that oxytocin may mediate luteal demise in the primate. The mechanism of action and the source of this biochemical signal are unknown. Flint \& Sheldrick (1983) suggest that, in sheep, luteal oxytocin may contribute to luteolysis via a systemic action involving the appearance of oxytocin in the ovarian vein caused by PGF- $2 \alpha$ (Sheldrick \& Flint, 1983). However, hysterectomy does not alter ovarian periodicity in primates (Neill, Johansson \& Knobil, 1969; Castracane, Moore \& Shaikh, 1979), and so the ovary bearing the corpus luteum or the corpus luteum itself must be considered. Peripheral infusions of oxytocin at the same dose rate (10 mi.u./h) have not been done, but Wilks (1983) has reported that pharmacological intramuscular 
injections of oxytocin (2250 i.u.) on Day 6 of the normal primate luteal phase did not alter corpus luteum function, suggesting a local rather than systemic effect of oxytocin. Auletta et al. (1984) have shown that PGF-2 $\alpha$ infused chronically into the primate corpus luteum, but not into the stroma of the contralateral ovary, peripherally or the same dose $(10 \mathrm{ng} / \mathrm{h})$ to the stroma of the corpus luteumbearing ovary ( $F$. J. Auletta, unpublished data), caused functional luteal regression. Furthermore, oestrogens have been shown to stimulate oxytocin release in man (Amico, Seif \& Robinson, 1981), stimulate PGF- $2 \alpha$ release from the corpus luteum-bearing ovary in the monkey (Auletta et al., 1978), and induce oxytocin receptors in the endometrium (Roberts, McCracken, Gavagan \& Soloff, 1976; McCracken, 1980). These observations suggest that oestrogens may be the biochemical signal responsible for the synthesis and release of PGF- $2 \alpha$ and oxytocin.

This research was supported in part by NIH grant HD-15444 and a Burroughs-Wellcome Travel Grant (to F.J.A.). We thank the National Pituitary Agency for the generous gift of crude monkey LH standard (LER 1909-2), Dr D. Collins for the oestradiol antiserum, and Betty Twitchell for assistance in preparing the manuscript.

\section{References}

Amico, J.A., Seif, S.M. \& Robinson, A.G. (1981) Oxytocin in human plasma: correlation with neurophysin and stimulation with estrogen. J. clin. Endocr. Metab. 32, 988-993.

Armstrong, D.T. \& Hansel, W. (1959) Alteration of the bovine estrous cycle with oxytocin. J. Dairy Sci. 42, 533-542.

Auletta, F.J., Currie, G.N. \& Black, D.L. (1972a) Effect of oxytocin and adrenergic drugs on bovine reproduction. I. Estrous cycle lengths and peripheral blood progesterone. Acta endocr., Copenh. 69, 241-248.

Auletta, F.J., Caldwell, B.V., van Wagenen, G. \& Morris, J.McL. (1972b) The effect of postovulatory estrogen on progesterone and prostaglandin $F$ levels in the monkey. Contraception 6, 411-421.

Auletta, F.J., Agins, H. \& Scommegna, A. (1978) Prostaglandin F mediation of the inhibitory effect of estrogen on the corpus luteum of the rhesus monkey. Endocrinology 103, 1183-1189.

Auletta, F.J., Kamps, D.L., Pories, S., Bisset, J. \& Gibson, M. (1984) An intra-corpus luteum site for the luteolytic action of prostaglandin $F 2 \alpha$ in the rhesus monkey. Prostaglandins 27, 285-298.

Black, D.L. \& Duby, R.T. (1965) Effect of oxytocin, epinephrine and atropine on the oestrous cycle of the cow. J. Reprod.Fert. 9, 3-8.

Castracane, V.D., Moore, G.T. \& Shaikh, A.A. (1979) Ovarian function in hysterectomized Macaca fascicularis. Biol. Reprod. 20, 462-472.

Cooke, R.G. \& Knifton, A. (1981) Oxytocin-induced oestrous in the goat. Theriogenology 16, 95-97.

Fairclough, R.J., Moore, L.G., McGowan, L.T., Peterson, A.J., Smith, J.F., Tervit, H.R. \& Watkins, W.B. (1980) Temporal relationships between plasma concentrations of 13,14-dehydro-15-keto-prostaglandin $\mathrm{F}$ and neurophysin $\mathrm{I} / \mathrm{II}$ around luteolysis in sheep. Prostaglandins 20, 199-208.

Falconer, J., Mitchell, M.D., Mountford, L.A. \& Robinson, J.A. (1980) Plasma oxytocin concentrations during the menstrual cycle in the rhesus monkey, Macaca mulatta. J. Reprod. Fert. 59, 69-72.
Fields, P.A., Eldridge, R.K., Fuchs, A.R., Roberts, F.R. \& Fields, M.J. (1983) Human placental and bovine corpora lutea oxytocin. Endocrinology 112, 15441546.

Flint, A.P.F. \& Sheldrick, E.L. (1982) Ovarian secretion of oxytocin is stimulated by prostaglandin. Nature, Lond. 297, 587-588.

Flint, A.P.F. \& Sheldrick, E.L. (1983) Evidence for a systemic role for ovarian oxytocin in luteal regression in sheep. J. Reprod. Fert. 67, 215-225.

Horton, E.W. \& Poyser, N.L. (1976) Uterine luteolytic hormone: a physiologic role for prostaglandin $\mathrm{F} 2 \alpha$. Physiol. Rev. 56, 595-651

Khan-Dawood, F.S. \& Dawood, M.Y. (1983) Human ovaries contain immunoreactive oxytocin. J. clin. Endocr. Metab. 57, 1129-1132.

Khan-Dawood, F.S., Marut, E.L. \& Dawood, M.Y. (1984) Oxotycin in the corpus luteum of the monkey. Endocrinology 115, 570-574.

McCracken, J.A. (1980) Hormone receptor control of prostaglandin F $2 \alpha$ secretion by the ovine uterus. $A d v$. Prostaglandin Thromboxane Res. 8, 1329-1344.

Milne, J.A. (1963) Effects of oxytocin on the oestrous cycle of the ewe. Aust. Vet. J. 39, 51-52.

Mitchell, M.D., Haynes, P.J., Anderson, A.B.M. \& Turnbull, A.C. (1981) Plasma oxytocin concentrations during the menstrual cycle. Eur. J. Obstet. Gynecol. Reprod. Biol. 12, 195-200.

Neill, J.D., Johansson, E.D.B. \& Knobil, E. (1969) Failure of hysterectomy to influence the normal pattern of cyclic progesterone secretion in the rhesus monkey. Endocrinology 84, 464-465.

Roberts, J.S., McCracken, J.A., Gavagan, J.E. \& Soloff, M.S. (1976) Oxytocin stimulated release of prostaglandin $F 2 \alpha$ from ovine endometrium in vitro: correlation with oestrous cycle and oxytocin-receptor binding. Endocrinology 99, 1107-1114.

Sheldrick, E.L. \& Flint, A.P.F. (1981) Circulating concentrations of oxytocin during the estrous cycle and early pregnancy in sheep. Prostaglandins 22, 631636. 
Sheldrick, E.L. \& Flint, A.P.F. (1983) Regression of the corpora lutea in sheep in response to cloprostenol is not affected by loss of luteal oxytocin after hysterec. tomy. J. Reprod. Fert. 68, 155-160.

Sheldrick, E.L., Mitchell, M.D. \& Flint, A.P.F. (1980) Delayed luteal regression in ewes immunized against oxytocin. J. Reprod. Fert. 66, 75-78.

Steel, R.G.D. \& Torrie, J.H. (1960) Principles and Procedures of Statistics, pp. 73-87. McGraw-Hill, New York.

Tan, G.J.S., Tweedale, R. \& Biggs, J.S.G. (1982) Oxytocin may play a role in the control of the human corpus luteum. J. Endocr. 95, 65-70.
Theeuwes, F. \& Yum, S.L. (1970) Principles of the design and operation of generic osmotic pumps for the delivery of semisolids or liquid drug formulations. Annls Biomed. Eng. 4, 343-353.

Wathes, D.C. \& Swann, R. (1982) Is oxytocin an ovarian hormone? Nature, Lond. 297, 225-227.

Wathes, D.C., Pickering, B.T., Swann, R., Porter, D.G., Hull, M.G.R. \& Drife, J.D. (1982) Neurohypophyseal hormones in the human ovary. Lancet 2, 410-412.

Wilks, J.W. (1983) The effect of oxytocin on the corpus luteum of the monkey. Contraception 28, 267-272.

Received 7 February 1984 